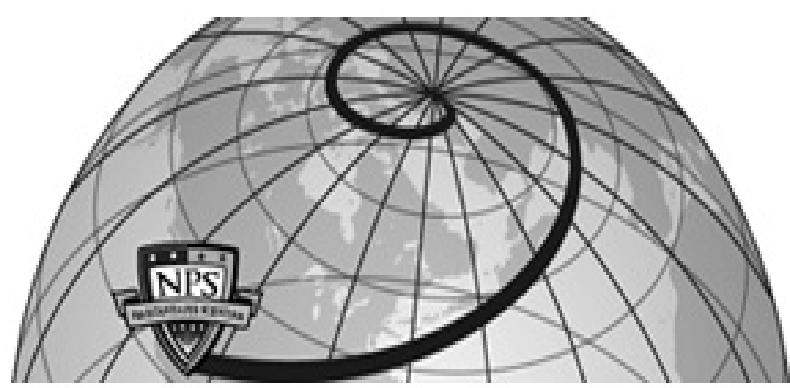

Calhoun: The NPS Institutional Archive DSpace Repository

Situated Entrepreneurial Cognition

Dew, Nicholas; Grichnik, Dietmar; Mayer-Haug, Katrin; Read, Stuart; Brinckmann, Jan

International Journal of Management Reviews, 2014

https://hdl.handle.net/10945/45317

This publication is a work of the U.S. Government as defined in Title 17, United States Code, Section 101. Copyright protection is not available for this work in the United States.

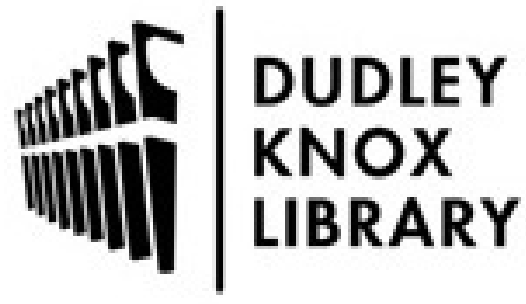

http://www.nps.edu/library
Calhoun is the Naval Postgraduate School's public access digital repository for research materials and institutional publications created by the NPS community. Calhoun is named for Professor of Mathematics Guy K. Calhoun, NPS's first appointed -- and published -- scholarly author.

Dudley Knox Library / Naval Postgraduate School 411 Dyer Road / 1 University Circle Monterey, California USA 93943 


\title{
Situated Entrepreneurial Cognition
}

\author{
Nicholas Dew, Dietmar Grichnik ${ }^{1}$, Katrin Mayer-Haug ${ }^{2}$, Stuart Read ${ }^{3}$ and \\ Jan Brinckmann ${ }^{4}$ \\ Naval Postgraduate School, 1 University Circle, Monterey, CA 93943, USA, ${ }^{1}$ University of St. Gallen, \\ Dufourstrasse 40a, 9000 St. Gallen, Switzerland, ${ }^{2}$ WHU - Otto Beisheim School of Management, Burgplatz 2, \\ 56179 Vallendar, Germany, ${ }^{3} \mathrm{IMD}$, Chemin de Bellerive 23, PO Box 915, 1001 Lausanne, Switzerland, ${ }^{4}$ ESADE \\ Graduate School of Business, Avenida Pedralbes 60-62, 08034 Barcelona, Spain \\ Corresponding author email: dietmar.grichnik@unisg.ch
}

\begin{abstract}
This paper reviews and integrates research from both within and outside the entrepreneurship field under the label of 'situated cognition'. Situated cognition is the notion that cognitive activity inherently involves perception and action in the context of a human body situated in a real-world environment. The review concentrates on three areas of the situated cognition literature that have significant implications for research in entrepreneurial cognition: embedded, grounded and distributed cognition. While these three aspects of cognition differ in terms of foci and core theses, they share the common emphasis of viewing and investigating cognitive processes by going beyond the individual mind and paying attention to the human body, (material) objects and other people. Using the theoretical lens of situated cognition provides new insights into current entrepreneurship phenomena such as co-creation and interaction in a shared economy based on new technologies.
\end{abstract}

\section{Introduction}

Research into entrepreneurial cognition endeavors to understand how some individuals identify and act to exploit entrepreneurial opportunities, and why others do not (McMullen and Shepherd 2006). Beginning with the premise of bounded cognition, research in the field has pursued questions around the ways in which cognitive processes inhibit effectiveness in the face of risks, ambiguities and uncertainties inherent in the entrepreneurial process (e.g. research on biases, heuristics and overconfidence) (Busenitz and Barney 1997; Hayward et al. 2006). At the same time, another body of research has explored ways in which cognitive processes are sometimes adapted to

We express our deep gratitude to Joep Cornelissen and three anonymous reviewers for their incredibly thoughtful comments and suggestions that significantly improved this paper. The usual disclaimers apply. enable superior performance, e.g. research on pattern recognition, meta cognition and expert scripts (Baron and Ensley 2006; Haynie et al. 2010; Mitchell et al. 2000). However, whether geared to the inhibitors or enablers of performance, the field has been dominated largely by individualistic and static conceptions of entrepreneurial cognitions that cognition researchers have increasingly critiqued as 'boxologies' and rejected as an appropriate basis for understanding cognition (Mitchell et al. 2011). The prevailing conceptions of cognition, it is argued, fall short of capturing the 'gist' (Shepherd and Sutcliffe 2011) of the phenomenon they purport to describe, which is characterized by dynamism and interactivity. Therefore, scholars in the area have called for new conceptualizations of entrepreneurial cognition that capture these inherent qualities of entrepreneurial phenomenon (Venkataraman et al. 2012).

This paper reviews and integrates research from both within and outside the entrepreneurship field under the label of 'situated cognition' (Clark 2010; 
Joas 1996; Robbins and Aydede 2009a; Wilson 2002). Situated cognition is the notion that cognitive activity inherently involves perception and action in the context of a human body situated in a real-world environment (Mitchell et al. in press; Wilson 2002, p. 626). Early sources of the fundamental ideas of situated cognition can be traced at least to William James and other 19th-century philosophers and psychologists (Prinz 1987). Some important outcrops of work have already appeared in the entrepreneurship literature that embrace a situated view of cognition (e.g. Cornelissen and Clarke 2010; Cornelissen et al. 2012; Doganova and Eyquem-Renault 2009; Mitchell et al. 2011; Randolph-Seng et al. in press), but we contend that the field has yet to pay enough attention to the issues highlighted by this work and by the broader literature on this topic. This review is targeted at concisely analyzing and organizing several of the major themes that have emerged in situated cognition research and are relevant to the investigation of entrepreneurial cognition, in order to progress the development of research implications and opportunities for situated entrepreneurial cognition research (Randolph-Seng et al. in press).

As with any effort to review and import research from a general field into a discipline such as entrepreneurship, a central question is the identification and choice of relevant theoretical issues. Many examples of situated cognition discussed in the literature are epiphenomenal to entrepreneurship, i.e. driving, making a presentation, holding a conversation, running a multi-person meeting, catching a baseball or playing in a soccer game. These are all things entrepreneurs might do (some of them on a daily basis), but are not tasks or activities that are distinctly entrepreneurial, that characterize the discipline of entrepreneurship. Some might even think them to be trivial. This leads us to concentrate on a few areas of the situated cognition literature where we believe the cash value (James 1904) of theoretical insights from the broader field is the highest for entrepreneurial cognition research. We organize these in an analytical framework in Figure 1, which differentiates key themes in the situated cognition literature that will form the focus of our investigation.

Our framework recognizes and partially integrates several proposed alternatives that have been offered in the literature (Anderson 2003; Clancey 1997; Clark 1999; Smith and Semin 2004; Wilson 2002) for organizing what is a very broad and diverse body of research encompassing psychology, cognitive science, linguistics, philosophy, artificial intelligence, social psychology and others (Clark 2010). This work can be usefully summarized as in Figure 1

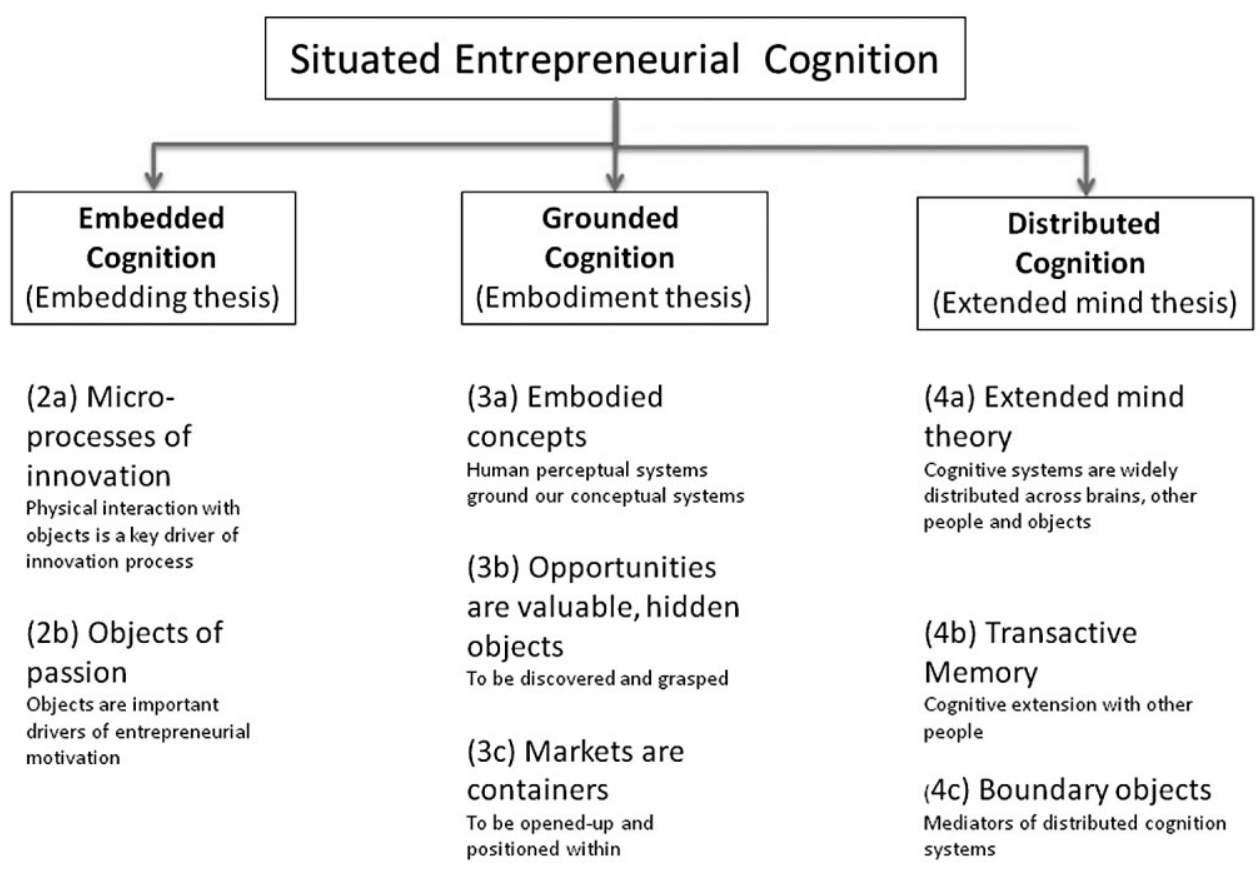

Figure 1. Research framework 
in three major theses that collectively define work in the area (Robbins and Aydede 2009a).

First, the 'embedding thesis' proposes that cognition is geared to action in the natural and social environment, and therefore has evolved in myriad ways to exploit objects and social structure available in these environments (Clark 1997). As Hutchins (2006, p. 394) describes it:

Human minds did not evolve in isolation, each wrapped tightly in a thick skull and thereby insulated from the complexities of the body and the world. We know that the brain takes advantage of minute details of the body and the body's interaction with the physical environment.

In fact, one of the most accepted propositions in the whole of situated cognition research is the idea that cognition is scaffolded and shaped in important ways by material objects available in the environment (Robbins and Aydede 2009b). While many aspects of embedded cognition that are discussed in the literature (e.g. assembling a product by laying out the pieces in the order and relationship they need to have in the finished item - Wilson 2002, p. 629) only peripherally relate to entrepreneurship, two aspects that are highly relevant occur in the innovation process. The role of cognitive offloading is significant in the learning-by-doing process, and material objects such as physical products (e.g. the personal computer or the smartphone) are powerful sources of interest, desire and passion that motivate entrepreneurial innovation. Thus, we highlight a general case for better understanding the embedding of entrepreneurial activity in the material environment, in particular the role of specific objects that are such central features of entrepreneurial work.

The second thesis holds that cognitive processes have deep roots in the body, in particular in its sensorimotor capabilities. It is referred to as the 'embodiment thesis' (Robbins and Aydede 2009b): the idea that cognition 'arises from bodily interactions with the world' (Thelen et al. 2001, p. 1). Within this literature the role of the body has been considered in several different ways. For example, one way in which cognition is situated in the body is observed in how we employ our bodies to grease the wheels of our thought processes, e.g. through physical actions such as gesturing (Cornelissen et al. 2012; Goldin-Meadow and Wagner 2005; Hostetter and Alibali 2008; Iverson and Goldin-Meadow 1998; McNeill 2005). However, we consider many of these themes to be peripheral to the central issues concerning entrepreneurial cognition. Instead, the aspect of embodiment we identify as the main concern is the grounding of concepts, what Anderson (2003) calls the 'physical grounding project' in the embodied cognition literature (Lakoff and Johnson 1999). In the past fifteen years the notion that our perceptual systems at least partially ground our conceptual systems has garnered considerable research support (Barsalou 2010; Wilson 2002) and, as we will show, grounded cognition is an idea that has significant implications for the conceptualization of entrepreneurial behavior both by researchers and entrepreneurs themselves.

The third, most challenging, thesis is the claim that, taken to its logical conclusion, 'mind' is best understood as extending beyond the boundaries of the individual to incorporate a broader system of interacting elements, known as the 'extended mind thesis' (Clark and Chalmers 1998; Robbins and Aydede 2009b). Again, this thesis can be separated into different claims that it is useful to disentangle (Wilson 2002). The one that we are persuaded is most relevant to entrepreneurial cognition research is the idea that cognition is fundamentally distributed across social agents (Hutchins 1995a; Smith and Semin 2004). We therefore take up the issue of socially distributed cognition (West 2007) by shifting the unit of analysis for cognition to the collective level and reviewing two mechanisms that facilitate the distribution of cognition across social agents in entrepreneurial situations. Here, our focus will be on transactive memory and boundary objects (Star and Griesemer 1989; Wegner 1987) though we recognize that a wide range of contributions to this topic exist (Klotz et al. 2014).

Collectively, these three theses paint an image of cognitive process as highly interactive and rooted in the physical, material and social context of individuals (Robbins and Aydede 2009a). This view of the mind therefore rejects the image of cognition as information processing that can be usefully abstracted from the body and outside world (Smith and Semin 2004), i.e. '[T]he cognitivist claim that cognition is the rule-based manipulation of abstract representations.' (Anderson 2003, p. 126). This image of pure information processing is the core target of criticism from the situated cognition perspective. It is an image that can be succinctly summed up as mentalism: the notion that the domain of cognition research lies purely inside the head (Agre 1997). Much of the research program of 
situated cognition therefore attacks the assumption that agents think mainly using abstractions (analogs, scripts and simulations of the world in the head), arguing instead that cognition involves considerably more than mental representation alone (Clark 2010). Instead, connections to the body, the outside material world and social others are theoretically salient for understanding how the 'full spectrum' of thinking occurs (Randolph-Seng et al. in press, p. 13). These issues are important for entrepreneurial cognition research because the theoretical lens of situated cognition provides new insights to current entrepreneurship phenomena such as co-creation and interaction in a shared economy based on new technologies.

Of course, like every research topic, the notion of situated entrepreneurial cognition stands on the shoulders of much research that has come before. As already referenced, several threads of work have appeared in the entrepreneurship literature in recent years that pertain to a situated cognitive perspective. These are covered in more depth than we have space for here by Randolph-Seng et al. (in press) and the interested reader is encouraged to use that text as a definitive reference for the progression of entrepreneurial cognition research towards a more situated approach. Here we present a summative table (see Table 1) that organizes several of the most important pieces of work according to the main categories of our exposition: embedded, grounded and distributed cognition.

Starting with the notion of cognition being embedded in the broader environment, perspectives on this issue can be traced to work by Krueger et al. (2000) that sought to broaden the investigation of entrepreneurial intentions to include the influence of situational factors on intentions. Baron (2008) also portrayed affect as highly situational in his research on the role of affect in entrepreneurship, a theme that continued in work by Cardon and colleagues (Cardon et al. 2009; Drnovšek et al. 2009), who built a model of entrepreneurial passion that foregrounded, among other things, the role of material objects as sources of passion. At the same time, other researchers have developed insights into the usefulness of grounded cognition for entrepreneurship research. Two major themes have been advanced here: first, the role of the physics of the body and brain (Baucus et al. in press; Nicolaou et al. 2008; White et al. 2007); and second, the theme of conceptual embodiment, developed in the work of Cornelissen and colleagues (Cornelissen 2013; Cornelissen and Clarke 2010; Cornelissen et al. 2012). Third, further work in entrepreneurial cognition has also elaborated the issue of distributed cognition, work that can be traced to contributions made by Mitchell et al. (2000) in examining the similarity in cognitive scripts used across cultures, to de Carolis and Saparito (2006) on the distribution of cognition across social networks and West (2007) on collective cognition, through to recent work on transactive memory in start-up teams (Zheng 2012).

The structure of this paper follows the contours outlined in the introduction and exhibited in Table 1 and Figure 1. In the next section, we take up the issue of the embeddedness of cognition, with a focus on the role of material things in innovative work and as objects of entrepreneurial passion. Following that, our exposition turns to the grounding of cognition in the body's perceptual apparatus, i.e. the notion that our conceptual systems are ultimately based in large part on our physical perceptual and motor systems. The fourth section takes up the distribution of cognition among social agents, examining the twin themes of boundary objects and transactive memory as important mechanisms through which distributed cognition is enabled. Finally, we circle back to a discussion of key issues raised in our exposition, and to questions about what research entrepreneurship scholars might fruitfully engage in next to build on the legacy that current work has established. Throughout, we note that this review necessarily cannot encompass everything of issue and every work of research that knowledgeable scholars collectively might point to, and readers are reminded that the usual disclaimers apply.

\section{Embedded cognition}

\section{Micro-processes of innovation}

A key activity of entrepreneurs - widely regarded as a sine qua non of the entrepreneurial role - is creating, adapting and bringing new ideas to market (Baumol 2010; McMullen and Shepherd 2006; Schumpeter 1976; Shane and Venkataraman 2000). Very often, these innovations are material objects, some famed examples synonymous with famed entrepreneurs being luxury china (Josiah Wedgwood, pictured at a table of them), personal computers (Steve Jobs, cover of Time magazine cradling one), the automobile (Henry Ford, the usual image is of him sitting in one), and the airplane (Howard Hughes, flying one - fast). Objects are something that people act towards and with, which can include representations (e.g. designs, ideas, theories that 
Table 1. Entrepreneurship cognition research pertaining to situated cognition

\begin{tabular}{|c|c|}
\hline Articles (date-ordered) & Summary \\
\hline \multicolumn{2}{|l|}{ Embedded cognition } \\
\hline Krueger et al. (2000) & $\begin{array}{l}\text { Highlights the influence of exogenous situational factors on entrepreneurial intentions, } \\
\text { indicating the embedded nature of intentions. }\end{array}$ \\
\hline Baron (2008) & $\begin{array}{l}\text { Examines the role of affect in entrepreneurial decision-making, which is portrayed as highly } \\
\text { situational, hence environmentally embedded. }\end{array}$ \\
\hline Cardon et al. (2009) & $\begin{array}{l}\text { Highlights the role of entrepreneurial passion, the importance of affect as an embodied } \\
\text { experience, and centrality of venture-related objects of passion. }\end{array}$ \\
\hline Clarke (2011) & Examines the role of visual symbols in entrepreneurial sense-giving. \\
\hline Mitchell et al. (2011) & $\begin{array}{l}\text { Proposes usefulness of concept of socially situated cognition, drawing on Smith and Semin } \\
\text { (2004), and illustrated with examples from entrepreneurship literature. }\end{array}$ \\
\hline Randolph-Seng et al. (in press) & $\begin{array}{l}\text { Proposes socially situated cognition as an overarching framework for research on } \\
\text { entrepreneurial cognition: 'At the center of the socially situated cognition approach is the } \\
\text { idea that cognition is not static but situated within specific individuals and environments.' }\end{array}$ \\
\hline Mitchell et al. (in press) & $\begin{array}{l}\text { Suggests ways to incorporate non-conscious cognitions into entrepreneurial cognition research, } \\
\text { emphasizing environmental factors that affect non-conscious cognitions, hence the } \\
\text { embeddedness of non-conscious cognition. }\end{array}$ \\
\hline Drnovšek et al. (in press)] & Introduces the concept of situated emotions. \\
\hline \multicolumn{2}{|l|}{ Grounded cognition } \\
\hline Nicolaou et al. (2008) & Influence of the body (genetics) on individuals' propensity to engage in entrepreneurial activity. \\
\hline White et al. (2007) & $\begin{array}{l}\text { Influence of the body (hormones, e.g. testosterone levels) on willingness to engage in } \\
\text { entrepreneurship. }\end{array}$ \\
\hline Cornelissen and Clarke (2010) & $\begin{array}{l}\text { Argues for the incorporation of motor actions in sense-making by entrepreneurs: '[M]otor } \\
\text { actions involving physical movement or physically holding or manipulating an object' shape } \\
\text { metaphorical induction about a new venture.' (p. } 547) \text {. }\end{array}$ \\
\hline Clarke and Cornelissen (2011) & $\begin{array}{l}\text { Embraces an embodied view of cognition, suggesting that 'words and grammatical } \\
\text { constructions will reference certain basic cognitive categories (e.g. objects, motion, } \\
\text { causation, agency, etc.).' }\end{array}$ \\
\hline Cornelissen et al. (2012) & Examines the use of gesturing and use of embodied metaphor in sense giving of entrepreneurs. \\
\hline Cornelissen (2013) & Uses examples of embodied cognition in life of Steve Jobs and Van Gogh. \\
\hline Baucus et al. (in press) & Reviews physical neuroscience pertinent to entrepreneurial cognition research. \\
\hline \multicolumn{2}{|l|}{ Distributed cognition } \\
\hline $\begin{array}{l}\text { Mitchell, Smith, Seawright } \\
\text { and Morse, } 2000\end{array}$ & $\begin{array}{l}\text { Suggests that consistency in entrepreneurial cognitions across cultures indicates distributed } \\
\text { cognition occurs as common forms of entrepreneurial expertise. }\end{array}$ \\
\hline De Carolis and Saparito (2006) & $\begin{array}{l}\text { Suggests that entrepreneurship is the result of the interplay of environment (i.e. social } \\
\text { networks) and cognition (i.e. cognitive biases) of entrepreneurs. }\end{array}$ \\
\hline West (2007) & Role of collective cognition in shaping an entrepreneurial venture. \\
\hline Cardon (2008) & $\begin{array}{l}\text { Explains how physical mimicry is an important factor influencing the contagion of } \\
\text { entrepreneurial passion. }\end{array}$ \\
\hline $\begin{array}{l}\text { Doganova and Eyquem- } \\
\text { Renault (2009) }\end{array}$ & Role of business models as boundary objects that play a role in network and market formation. \\
\hline Zheng (2012) & Role of transactive memory among venture founding teams. \\
\hline Breugst et al. (2012) & $\begin{array}{l}\text { Shows how contagion of passion matters in explaining how employees' perceptions of } \\
\text { entrepreneurial passion that influences employees' commitment to ventures. }\end{array}$ \\
\hline Mitchell et al. (in press) & Introduce simulation to disembody and re-embody exchange cognitions. \\
\hline
\end{tabular}

represent processes or services) as well as material objects (e.g. products and goods) (Nicolini et al. 2012, p. 613, p. 617).

Recent entrepreneurship research (e.g. Cornelissen et al. 2012) has explicitly highlighted the physical role of human bodies and the material things that they see, touch and connect with, in the study of entrepreneurial cognition. This focus on entrepreneurial bodies and material objects seems natural because object-focused innovation pervades entrepreneuring - particular material things are frequently the primary reason why entrepreneurs become entrepreneurs in the first place - and entrepreneurs need bodies (as well as brains) to interact with most, if not all, material objects (including other people, in the case of service innovations).

Such research highlights the two-way physical interaction between entrepreneurs and objects, and 
what Klemmer et al. (2006, p. 142) refer to as the 'backtalk' that objects provide. Using the example of prototypes in the design of ubiquitous computing devices (e.g. music players, mobile phones and digital cameras), they argue that:

$[\mathrm{P}]$ hysical action and cognition are interconnected. Successful product designs result from a series of 'conversations with materials.' Here, the 'conversations' are interactions between the designer and the design medium - sketching on paper, shaping clay, building with foam core ... The epistemic production of concrete prototypes provides the crucial element of surprise, unexpected realizations that the designer could not have arrived at without producing a concrete manifestation of her ideas. (Klemmer et al. 2006, p. 142)

The transactions ('conversation') between mind, body and world in this example foregrounds a major theme from situated cognition research on embedding: the idea of cognitive 'off-loading' (Robbins and Aydede 2009b). Instead of generating a mental model of the problem-solving requirement, storing it and then manipulating it, we turn the problem into a visual task where we physically manipulate the object itself until we 'see' what works (Lindblom 1959). We therefore tune down the demands for a full-blown cognitive representation of problem situations in favor of the more economical solution of using the 'world as its own model' (Brooks 1991, p. 140 ) and the 'world as an outside memory' (O'Regan 1992, p. 461). Thus, our flow of thoughts depends on repeated environmental interactions (Anderson 2003, p. 108; Clark 1997; Tribble 2005) rather than on producing a cognitive model within which we step back, observe, assess and plan our actions (Wilson 2002, p. 628).

As a theoretical mechanism off-loading is also important in entrepreneurship because of a second major theme in situated cognition research, which is the role of physical interaction in learning. In observing child development, Piaget (1952) argued that cognitive development requires both mental activity and physical interaction in the world. This theme is familiar to scholars of learning-by-doing in innovation, which is widely considered to be a vital practice in innovation (Von Hippel and Tyre 1995). Entrepreneurship involves much hands-on tinkering with material objects: mock-ups, prototypes or preproduction products (Bettiol et al. 2013; Rosenberg 1976). It is easier for entrepreneurs to cognitively lean on the world by physically manipulating mockups (Thomke 2003) than it is to engage in building a complete cognitive model of a new product design, and then producing that design. Despite the recurring image of the entrepreneur as someone experiencing an 'Aha!' moment in which a metaphorical light bulb comes on, the situated cognition literature suggests instead that the development of new product ideas is something that happens in much more of a hands-on fashion, where entrepreneurs build material objects in order to think and experience incremental 'Ahas' (Bettiol et al. 2013, p. 5). In reviewing two books on the lives of Van Gogh and Steve Jobs respectively, Cornelissen (2013) observes:

[B]odily actions, including speech, gesturing and drawing, do not simply express previously formed mental concepts but they are part and parcel of the very activity in which conceptualizations and inferences are formed ... Van Gogh and Jobs are the very embodiment of this very insight in that every physical stroke or design choice provoked further thoughts and ideas and led them to refine their thinking about a particular painting or product. (Cornelissen 2013, pp. 16-17)

Thus, learning emerges from interacting with and manipulating material objects that grease the wheels of the thought process.

Numerous other examples underscore the notion that entrepreneurs build things and physically interact with them in order to think better about innovative problem-solving. The notion of constructing some type of workable, recognizable material object (Jacob 1977) has long been highlighted as a critical stepping stone in the innovation process, suggesting that materiality is vital to the process. In a study of debugging new manufacturing equipment Tyre and Von Hippel (1997, p. 76) found that, in all but two of the 27 problems studied, some direct visual inspection was necessary for engineers to grasp the nature of the problem, concluding that, 'Seeing, touching, and manipulating are obviously important avenues for improving understanding, just as hearing and explaining are; yet, they are nearly overlooked in the organizational literature.' In a recent study of design processes, the authors highlight that the latest digital design technologies were used sometimes, though less often than low-tech methods such as quick construction of models using paper, cardboard, plywood and other cheap materials (Austin et al. 2012). This preference for low-tech, craft-based design makes 
perfect sense when the situated nature of cognition is understood. The human brain has remarkable mental simulation capabilities (i.e. imagination). However, these capacities are limited by the brain's short-term memory capacity. It is much easier to off-load some of these simulation requirements, replacing the need for a complex internal model with 'seeing' by building a prototype and then physically manipulating it (Klemmer et al. 2006). What mental simulation does occur is made easier by using a prototype or model as a tangible anchor for cognitive manipulations (Hutchins 1995a), with problem-solving routines entailing repeated interaction between internal representation and computations, on the one hand, and manipulation of the material object, on the other (Anderson 2003).

Focusing on the role of tinkering as an important component of innovation is, of course, not new in innovation studies: Rosenberg (1976) and others long ago made the persuasive case that, when one breaks open the black box of innovation, one finds a craft, more than a science, historically dominated by hands-on tinkering that occurs in 'innumerable small increments ...' (Geroski 2003; Mokyr 1990; Rosenberg 1976, p. 78). The vast majority of all firms have no R\&D budget (Nooteboom 1994) and technical improvements are typically individually very modest. Current explanations of these processes tend to focus attention on explanatory factors that are extra-cognitive, e.g. on the locus and stickiness of information (von Hippel 1994). Situated cognition research adds insight about why innovation is approached in the very hands-on way it is, even in the presence of high-tech alternatives (Austin et al. 2012; Klemmer et al. 2006) by highlighting how offloading changes the ratio of material to cognitive inputs, thus leveraging cognitive embeddedness to improve task performance. This suggests that not only does the location and stickiness of information matter, but that bodies, material objects and cognition are 'constitutively entangled' (Orlikowski 2007, p. 1437) in the performance of innovative work.

\section{Objects of passion: situated entrepreneurial motivation}

By nature, innovative work is typically hard work with uncertain outcomes, and therefore intrinsic motivation matters significantly in entrepreneurship (Locke and Baum 2007). According to motivation theory (Heckhausen and Heckhausen 2008) motivation is object-bounded and, thus, objects are drivers of motivation. It is just as well, then, that entrepreneurs often seem obsessed with the objects they are trying to create, or create a market for (Cardon et al. 2009). Being embedded in a world of material objects matters not just because it affects microprocesses of innovation, but also because entrepreneurs frequently have special relationships with specific objects (or objectified ideas) - relationships that are influential in motivating them to do what they do. For Howard Schultz, the founder of Starbucks, it was the Italian Espresso bar (Davis et al. 2013), and his passion for it was manifest in his biography, Pour Your Heart Into It (Schultz and Jones Yang 1997). For Steve Jobs it was the personal computer, which he was obsessed about making 'insanely great' for over 30 years (Chen et al. 2009). For Rudolf Diesel, it was the diesel engine, with the process of materializing it almost comically described by Latour (1987). In fact, when it turned out that after much tinkering the initial batch of diesel engines kept breaking down and stopping working, Diesel himself had a nervous breakdown (Latour 1987, p. 106). Obsessions with particular types of objects drove the working (and personal) lives of these entrepreneurs and many others (Koehn 2000), making passion one of the most observed phenomenon in entrepreneurship (Smilor 1997). Indeed, it is hard to think of Schultz, Jobs or Diesel without thinking of the objects that motivated them.

Material objects can therefore tell us a lot about why entrepreneurs innovate and found new ventures to propagate their innovations in the first place. Entrepreneurial motivation is situated because it is embedded in material relations (Drnovšek et al. in press). Recent entrepreneurship research has noted this connection between material objects and powerful sources of motivation such as entrepreneurial passion. Cardon et al. (2009, pp. 515-516) suggest that " $[\mathrm{P}]$ assion involves "intense longing" that one feels for objects or activities that are deeply meaningful to one's identity, whether those objects are real, remembered, desired, imagined, or anticipated'. Passion is frequently described as the fire of desire that motivates entrepreneurs to persist with their efforts when obstacles occur (Chen et al. 2009). The literature therefore draws connections between entrepreneurial passion and performance outcomes (Baum and Locke 2004), funding success (Chen et al. 2009) and employee commitment (Breugst et al. 2012), citing the contagion effects of passion (Cardon 2008). However, in their review of numerous papers on entrepreneurial passion, Cardon et al. 
(2009, p. 512) draw the conclusion that in comparison with other work, we know little about the antecedents of passion. Furthermore, they characterize the literature as 'vague in identifying the object of entrepreneurial passion' and observe that 'the centrality of venture-related objects appears evident in conceptualizing entrepreneurial passion, but supporting theoretical work is lacking'.

Fortunately, contemporary literature on social studies of technology has examined the work objects perform in motivating action in some detail (Latour 1996; Nicolini etal. 2012; Orlikowski 2007; Vygotsky 1986). The theoretical framing of objects as foci of desire derives from the idea of epistemic objects (Cetina 1997; Rheinberger 1997), which can be understood as a theory of emotional attachment to objects. Objects are theorized to provide a source of interest and motivation for entrepreneurial work because of their incompleteness and openendedness. They are, so to speak, in need of being achieved (McClelland 1962) and the pursuit of achieving fuels emotional investment in and attachment to them (Baron 2007; Damasio 1994). The drive and desire to accomplish the object therefore lies at the root of an entrepreneur-object relationship, and these relationships can have a 'deep emotional holding power' over the entrepreneur, who may experience an 'intimate attachment' to their particular object of desire (Nicolini et al. 2012, p. 614).

From the foregoing, the theory of epistemic objects provides a persuasive explanation of the intrinsic motivation to innovate, which rests in part in the object itself (Heckhausen and Heckhausen 2008). The pursuit of something concrete - for example, a material object as a focus of the work - can help infuse energy and passion into a venture. Such objects can take many forms, including physical manifestations (diagrams, flowcharts) of new social arrangements, processes or services. But until the object is manifest, everything is talk and hot air. The innovation process is therefore partly grounded by the appearance of things at critical junctures - even if they are things that sometimes fall apart and have to be put back together again, as was the case with Rudolf Diesel's diesel engines (Latour 1987). Thus innovative works-in-progress, prototypes, semicreated, partial things - but things nonetheless - are material objects that make a venture real, and therefore are important fuel for mobilizing entrepreneurial behaviors (Swan et al. 2007).

Of course, entrepreneurial skills, traits and networks all matter: we are not saying they do not. Per
Nicolini et al. (2012, p. 613), we do not subscribe to the view that objects alone explain entrepreneurial innovation, only that a cognitive fundamental - motivation - is actively shaped by objects when entrepreneurs have a special relationship with them, as they often do (Smith and Semin 2004). In these instances entrepreneurial behavior cannot be made complete sense of without incorporating the fact that the activities we observe are in part the way they are because of what entrepreneurs are after, and not simply because of who the entrepreneur is (their personality characteristics), or because of their capabilities (human capital) or because they are inherently predisposed to such feelings (Cardon et al. 2009). Take away the objects, and it is like studying Howard Schultz without the coffee bar, Bill Gates without Windows, Milton Hershey without the chocolate, Enzo Ferrari without something fast and red, or studying Guy Laliberté in the absence of the clowns, the tent and the acrobats (that are Cirque du Soleil). The inherent involvement of material objects with entrepreneurial motivation suggests that the motives for entrepreneurship cannot be solely 'in the head', because such motivation is fundamentally situated, existing in the dynamic interaction of the brain with the material and social world in the making (Drnovšek et al. in press).

\section{Grounded cognition}

\section{Embodied concepts}

Ever wonder why new ventures are described as 'pivoting' in response to market opportunities (Ries 2011) or why new markets are described as 'blue oceans' (Kim and Mauborgne 2005) or why a new technology gets described as the 'face of things to come'? The explanation for these particular descriptions and many more like them rests with research on grounded cognition (Barsalou 2010).

Grounded cognition research highlights that cognitive tasks can be differentiated between online tasks where there is close-coupling between the agent and the environment (e.g. time-pressured interaction) and off-line tasks that are decoupled from immediate interaction with the environment (Robbins and Aydede 2009a; Wilson 2002). Typical examples of online tasks might be presenting a business plan to potential investors (Chen et al. 2009; Martens et al. 2007), running a staff meeting, driving a car or playing a soccer game (Clark 1997); activities in which perceptual information continues to 
flow while cognitive processes are being carried out (Wilson 2002). We routinely use our embodiment in such tasks: gesturing is an example of how online, live-time action is made easier by leveraging the body in order to think better (Cornelissen et al. 2012; Goldin-Meadow and Wagner 2005; Hostetter and Alibali 2008; Iverson and Goldin-Meadow 1998; McNeill 2005).

However, much of the type of thinking that entrepreneurial cognition researchers have typically concerned themselves with is more likely to be carried out off-line, occurring in the absence of immediate task-relevant inputs and outputs. Robbins and Aydede (2009b, p. 4) describe off-line processing as occurring when we disengage from the immediate environment, '[T]o plan, reminisce, speculate, daydream, or otherwise think beyond the confines of the here and now'. Off-line entrepreneurial cognitions could include searching for opportunities (Shane and Venkataraman 2000), imagining new products or services (Baker and Nelson 2005; Klein 2008), visioning market possibilities (Kirzner 1979), evaluating the feasibility and desirability of potential ventures (McMullen and Shepherd 2006) and planning particular courses of action (Frese et al. 2007). A key question for these types of off-line cognitions is how mental representations such as 'opportunities' come to have the meanings they do? (Anderson 2003; Harnad 1990; Prinz 2002). Why does the concept of opportunity (for example) make sense to entrepreneurs, or entrepreneurship cognition researchers, in the first place? What kind of sense does it make?

The grounded approach to cognition suggests that opportunities, pivoting, blue oceans and being the face of things to come are all examples of a more general phenomenon that the words, concepts and representations we routinely use have meaning because we can ultimately index them to the perceptual experiences we have in the real world, rather than deriving their meaning from the relationships between abstract, amodal symbols (Barsalou 2010; Cornelissen and Clarke 2010; Semin and Smith 2008; Wilson 2002). If this approach is correct, then off-line cognition is ultimately based in our perceptual and motor systems, and is contingent on our ability to move in the world (Anderson 2003, p. 126; Cornelissen and Clarke 2010, p. 547; Lakoff and Johnson 1999). This would mean that the very ways in which we are able to think - our most advanced cognitions - are ultimately shaped by the ways in which our cognitive systems use our bodies and environments as 'external informational structures that complement internal representations. In turn, internal representations have a situated character, implemented via simulations in the brain's modal systems, making them well suited for interfacing with external structures.' (Barsalou 2010, p. 717).

Evidence for the grounding hypothesis is strongest for concepts that involve visual and motor imagery because this is where concepts have the clearest relationship with perception and action. For an illustrative example, take Cornelissen's (2013) account of Steve Jobs' rationale for the iPod:

The rationale for the iPod, as a portable music player, pretty much grew out of the development of iTunes, the inference being that storing your music would naturally lead Apple to develop a playing device. But it also came about because of Steve Jobs' fanatical love for music. Isaacson describes in the book the admiration Jobs had for songwriters such as Bob Dylan as well as how he frequently recounted his very eclectic taste in music. This fanaticism gave Jobs a defining insight: he reasoned that we all build up our very personal archives of music with scores of purchased CDs reflecting our own taste. Our own music collections are by their very nature personal, and he in turn made the metaphorical association that if something is personal to us it is physically close to us (as opposed to distant). The typical association is that we metaphorically liken things that are personal, such as emotionally important relationships and friends, as physically close to our own bodies. The inference that came from this imaginative leap was that Jobs felt Apple needed to develop a portable music player, so that you could take your personal music collection with you - literally kept it close to you - wherever you went. (Cornelissen 2013, p. 15)

In this example, Cornelissen relates how higherorder cognitions about what is personal and emotionally important can be traced back to their bodily bases, in this case dominated by perceptions of physical closeness. Grounded cognition researchers add that, if it turns out that much of our thinking is similarly rooted in our experiences of space, then it would not be surprising that these instances inherit 'a kind of reasoning - a sense of how concepts connect and flow - which has its origin in, and retains the structure of, our bodily coping with space' (Anderson 2003, p. 105).

If grounding is implicated in cognition quite broadly, in the way researchers are coming to believe it is, it raises profound implications for how we think about key concepts in entrepreneurship. Pioneering 
work in entrepreneurship by Cornelissen and Clarke (2010, p. 547) and Cornelissen et al. (2012) has already pointed the way to a deeper consideration of the role of embodied concepts in the field by highlighting how concepts used in entrepreneurship are grounded in human motor actions, physical movement and perceptions of space, much as Lakoff and Johnson (1999) and others have argued them to be. These concepts (for example, planning as movement along a straight line (Cornelissen et al. 2012, p. 223) or technology commercialization as a journey with a prospective destination (Cornelissen et al. 2012, p. 228)) are also observed to be reinforced by and through the gestures entrepreneurs use to convey their meaning. Matching gestures can be considered to be a further indication of the perceptual grounding of concepts (Cornelissen et al. 2012, p. 218). Cornelissen and Clarke (2010, p. 546) add that we should expect less experienced entrepreneurs to routinely use grounded concepts to induce and subsequently give sense to their business ideas, whereas the more experienced are expected to use ready-tohand industry-specific analogies drawn from prior experiences.

To further illuminate these issues, we apply Lakoff and Johnson's (1999) approach to analyzing concepts as body-based metaphors to the concepts of 'opportunity' and 'market', which are both theoretically prominent in entrepreneurship. We may not consciously think of these concepts in metaphorical terms, yet an important prediction of the grounded cognition literature is that our concepts are generally structured in ways that reflect our physical embodiment, in particular reflecting our constant spatial experience in the world (Lakoff and Johnson 1999). Our basic level conceptualizations of this type happen below the level of consciousness and are therefore involuntary.

\section{Opportunities are valuable, hidden objects}

Take the concept of opportunities (Dimov 2007, 2010). Much of the entrepreneurship literature on opportunities has its roots in the foundational work of Austrian economists (Shane 2000; Shane and Venkataraman 2000), in particular Israel Kirzner's portrait of the role of entrepreneurs in the market process (Kirzner 1979, 1997). Kirzner's arguments rely on a system of metaphors in which opportunities are treated in much the same way as we commonly conceptualize ideas - as objects. Central to Kirzner's oevre is that opportunities are a rather special type of object: they are valuable, hidden objects. This leads Kirzner to use the metaphor of grasping an object to conceptualize how entrepreneurs behave: '[T]he entrepreneur grasps the opportunities for pure profit ...' (Kirzner 1997, p. 69). The conceptualization of opportunities as objects is palpable from Kirzner's use of the term 'grasping', but also from the action metaphor that Kirzner applies, which is 'discovery' (Hayek 1978) and from the associated metaphors that an opportunity might 'slip through the entrepreneur's fingers', that opportunity has to be 'seized' once it is discovered, that opportunities can be 'pursued' by entrepreneurs, that entrepreneurs sometimes 'get their hands on opportunities' (Lakoff and Johnson 1999, p. 197).

The metaphorical entailments of opportunities being hidden objects can be traced to the many ways in which opportunities are described in the literature (Venkataraman et al. 2008), for example:

- Entrepreneurs must discover opportunities that are otherwise out of sight.

- Some people are more alert than others at spotting opportunities.

- Some individuals may find and recognize them.

- Others overlook them or miss them completely.

- Opportunities can be elusive because they are concealed.

- Some entrepreneurs may have an internal compass that orients them in the direction of opportunities.

- Other entrepreneurs have better judgment about where opportunities are to be found.

Much of conceptual system surrounding opportunities in the entrepreneurship literature traces out other logical entailments of the 'opportunities are valuable hidden objects' metaphor, in the same way as Lakoff and Johnson (1999) analyze the work of major philosophers as being composed of tracing out the entailments of specific metaphors. Kirzner's notion of grasping opportunities by 'piercing the fog of uncertainty' (Kirzner 1985, p. 53) is a particularly colorful example, building on the opportunity metaphor with the metaphor of uncertainty as a form of visual impairment (owing to fog).

It is important to note that the ultimate point of tracing the metaphorical structure of these conceptual systems is the insight that they are both enabled and constrained by being grounded in the body's modal systems (Lakoff and Johnson 1999). For example, opportunities as valuable hidden objects predisposes us to a hunter-gatherer worldview of 
opportunities and therefore the types of entrepreneurial action that might work in that worldview. This masks alternatives, such as an agricultural worldview in which opportunities might be planted, nurtured, grown and harvested, or a creative worldview in which opportunities are fabricated, constructed, devised and engineered (Venkataraman et al. 2008).

\section{Markets are containers}

Using a similar approach, one can analyze the concept of markets via the 'Markets are containers' metaphor. Long ago, Fernand Braudel quizzically remarked: "[I]s it possible to "locate" the market in its proper place? This is not as easy as it might look, because the word "market" is itself equivocal.' (Braudel 1982, p. 223). One way of resolving this equivocality is to conceive markets in the way we perceive the world, which was already hinted at in Braudel's comment: many things are experienced as having distinct boundaries, and when they do not, we project boundaries on them by conceptualizing them as containers (Lakoff and Johnson 1980, p. 477; 1999, p. 32). Such spatial-relations concepts 'are at the heart of our conceptual system. (Lakoff and Johnson 1999, p. 30).

Containers have a gestalt structure: a boundary, an inside, an outside. The container schema can be physically instantiated (a room, a soccer field) and also imposed as a conceptual schema, as it frequently is for markets. Consider the conceptualization of markets by Fligstein (2001) as an example that makes the container schema overt. We see Fligstein (2001) describing the market as an arena, which has a classic container structure. Sellers and buyers meet 'in' the arena, they can be 'inside' it or on the 'outside'; when they want to trade they have to 'enter' the market. Elsewhere, Fligstein uses the field metaphor, another type of container. The container concept also became the foundation for Porter's (1980) approach to analyzing industries: the way to keep the market from 'overflowing' with competitors (too many 'players' spilling over the rim of the container) was to 'erect barriers to entry' (make the walls higher and more difficult to scale) that would 'constrain' the 'mobility' of would-be competitors (Caves and Porter 1977). This straightforward appeal to the container metaphor draws on the notion of physical boundaries that can 'impose forceful and visual constraints: it can protect a container's contents, restrict their motion ...' (Lakoff and Johnson 1999, p. 32).
Thus Porter traces out the entailments of the container metaphor. Research in entrepreneurship appeals to the same conceptual metaphors when describing international market entry by entrepreneurial firms (Zahra et al. 2000). Consider the following avalanche of spatial concepts clustered in this description of international entrepreneurship activity:

The number of productive opportunities open to a firm also multiplies when the firm enters a new market (Brush 1992; Penrose 1959). Entry gives the firm firsthand knowledge of the market and connects it with competitors, customers, suppliers, and innovation centers outside its domestic market (Birkinshaw 2000) - that is, the firm begins to build positional advantages within the new market. (Sapienza et al. 2006, p. 920)

Further entailments of the markets as containers metaphors frequently appear in research about, and conversations by, entrepreneurs (Venkataraman et al. 2008). For example:

- We have to get ahead of the competition in entering the market.

- We have to get to market first.

- We are exploring different market niches with this idea.

- We don't know yet which market space we should be in.

- One firm has ticked a piece of an open market to corral all to themselves.

- They are locking into a single area of that market.

- We have to protect our market leadership by blocking further entry.

- We have occupied a particular market niche.

- We are pushing into new market segments.

To sum up, the basis of mental representation is embodied metaphor, i.e. opportunities are objects to be found, markets are spaces with barriers, gaps can be found in those spaces, and niches positioned in (Lakoff and Johnson 1999). As Cornelissen and Clarke (2010) put it:

[E]ntrepreneurs often refer to 'leveraging' a client base, 'building' market awareness, 'expanding' market share, 'acquiring' market acceptance (Martens et al. 2007, p. 1118) ... In this way they metaphorically suggest that they can physically manipulate and control markets as if these were objects. (Cornelissen and Clarke 2010, p. 547) 
Innovative entrepreneurs pivot business models and change venture direction towards grasping new opportunities and disrupting existing market spaces. Recent entrepreneurship trends of technology-driven new markets such as 3D printing, big data, wearables (Google Glass), drivables (Google Car), flyables (Amazon's helicopter delivery) or commercial space travel (Spaceship One, SpaceX) could therefore be better explained with the grounded cognition of the embodiment thesis instead of relying on a purely information-processing phenomenon (Shane 2000).

\section{Distributed cognition}

\section{The idea of distributed cognition}

In this section we shift the focus of analysis to the role of 'other' individuals in cognition, i.e. to highlight that cognition is distributed across multiple agents. The distributed cognition thesis foregrounds the social aspects of cognition, that individual cognition involves cognitive transactions with other people as well as the shared use of certain types of material objects. If the basic insight of embeddedness is that we 'lean' on the world in ways that enhance our cognition, the distributed cognition thesis adds that the same principle holds when other people are the source of information and knowledge storage. Hence the idea that cognition is fundamentally distributed across social agents (Mitchell et al. 2011; Smith and Semin 2004).

The idea of distributed cognition is important because much entrepreneurial activity involves learning and spillovers from entrepreneur to entrepreneur, who do not work alone, but interactively and collectively (Friedel 2007; Garud and Karnøe 2003; Latour 1987; Uzzi 1997). In such systems, much of what we seek to understand about cognition takes place outside the heads of individuals, instead occurring in the interplay between them and other individuals that participate in the system. Similar observations led Hutchins (1995b, p. 267) to conclude that we can therefore, "[D]o a lot of research on the cognitive properties of such a system ... without saying anything about the processes that operate inside individual actors'. Smith and Semin (2004, p. 90) point out that this idea 'may seem odd' if a priori one limits the notion of cognition to something that only individual brains can do, but it ceases to seem odd if we instead consider cognition as a systemlevel property, arising among the actors that constitute a social system.
In this section of the paper, we selectively review two concepts that fit well within the idiom of distributed cognition and have already received considerable attention in the wider organizations literatures but are underdeveloped in entrepreneurial cognition research: 'transactive memory' (Hollingshead 1998; Wegner 1987; Zheng 2012) and 'boundary objects' (Carlile 2004; Spee and Jarzabkowski 2009; Star and Griesemer 1989). These concepts meet two key criteria to be included in this review: first, their efficacy and relevance to entrepreneurship is already proved by prior research using these ideas in the entrepreneurship domain (e.g. Doganova and Eyquem-Renault 2009; Zheng 2012) and, second, they are well-developed concepts with a broader literature that typifies the distributed cognition perspective by shifting the analysis to the system level in which multiple agents play a role in cognition. For these reasons, boundary objects and transactive memory both have the potential to scaffold future research on distributed cognition in entrepreneurship. We note that these concepts should be considered in the context of prior work in entrepreneurship that has already identified sense-making and sense-giving as core issues in thinking about distributed cognition (Cornelissen and Clarke 2010).

\section{Transactive memory: mind extension with other people}

Transactive memory is ' $[\mathrm{T}]$ he shared division of cognitive labor with respect to the encoding, storage, retrieval and communication of information from different knowledge domains, which often develops in close relationships' (Brandon and Hollingshead 2004 , p. 633). In a quite literal sense, transactive memory is the insight that other people are a key external resource for information and knowledge (Austin 2003). This insight is usually attributed to Wegner's (1987) study of married couples, which highlighted that, by specializing in particular types of information, married couples performed better on recall tasks than pairs of strangers. Wegner argued that this reflects the performance of a memory system among the married couples that consists in each person's knowledge repository plus mutual access to that knowledge via an indexing system, with is some degree of shared knowledge about who knows what (Wegner 1987). Thus, a transactive memory system can be thought of as 'a network of interconnected individual memory systems and the 
transfer of knowledge among them' (Majchrzak et al. 2007, p. 151).

Transactive memory therefore reflects social coupling in a distributed cognitive system in which the performance of the system is in part due to each actors' ability to access information and knowledge of other actors. Thus, actors cognitively 'lean' on each other, with their individual performances cognitively interdependent with other actors in the system (Brandon and Hollingshead 2004). However, with this interdependence comes a pragmatic division of cognitive labor that enables individuals to specialize in particular types of knowledge, a specialization that benefits the system performance. Indeed, research indicates that real working teams' extensive communication routines (regular email, phone, face-to-face, formal and informal conversations) leads them to develop fit-for-task transactive memory systems quite organically (Majchrzak et al. 2007).

The concept of transactive memory therefore falls naturally within the frame of situated cognition research as a well worked-out mechanism by which actors cognitively benefit from being around one another (Clark 1997): '[T] he cognitive powers of the individual mind are enhanced by socially available and accessible scaffolds. ... [T] his interdependent system is able to supply a more elaborate memory than any individual member' (Smith and Semin 2004, p. 93). Indeed, De Carolis and Saparito (2006, p. 41) argue that it makes sense to generalize this insight into the notion that 'entrepreneurial behavior is a result of the interplay of environments (i.e., social networks) and certain cognitive biases in entrepreneurs'.

The cognitive benefits of distributed cognition derive from shifting cognitive load to other people, using others to cue and prompt recall, and producing new knowledge and information by brainstorming with others, leading to faster problem-solving (Sutton and Hargadon 1996). For example, in his study of firms in the New York fashion industry, Uzzi (1997) observed that firms routinely lean on their social networks as external storehouses of information and knowledge that is retrieved when needed for joint problem-solving activity. Such benefits have traditionally been framed differently in the entrepreneurship literature, which has focused on the entrepreneur's distinctive knowledge as a facility for discovering opportunities that are unavailable to others (Shane 2000) and on the strategic use of social positions that provide privileged information access
(Burt 2009). Yet the dispersion of knowledge is double-edged. Closely held, it creates opportunities by compartmentalizing knowledge, which individuals benefit from when they can uniquely access it. Distributed, it also creates opportunities for deepening the collective knowledge base and using it by providing shared access to it.

Observations about the fundamental distribution of information and knowledge (and its economic consequences) are a familiar feature of entrepreneurial research, and can be traced back to Hayek (1945). While Hayek's commitment to methodological individualism led him to view cognition in atomistic terms (the plans of individual agents), the insight of situated cognition research is rather to see what analytical insights can be had from enlarging our view of cognition. This insight fits well with current entrepreneurship research on new ventures, which emphasizes that the locus of entrepreneurial activity often involves several individuals acting in a team. New ventures are commonly founded by teams rather than individuals (Klotz et al. 2014). This raises important questions about the mechanisms that link the team to venture performance, which includes team-level cognitive processes (Grégoire et al. 2011; West 2007), since the efficiency and effectiveness with which teams use and coordinate their knowledge, skills and abilities ought to affect venture performance (Zheng 2012). Research on founding teams vs. solo founders corroborates this expectation, finding that teams perform better than individuals (Cooper and Bruno 1977; Davidsson and Honig 2003; Eisenhardt and Schoonhoven 1990; Klotz et al. 2014). While some researchers have pointed out the potential negative effects of larger teams, such as challenges of coordination and communication (Blau 1970; Hare et al. 1965), or have attributed the performance enhancement of larger teams vs. solo founders to the resource of more available manpower, enabling working in parallel on various tasks (e.g. Davidsson and Honig 2003), others have rather highlighted the performance enhancement attributed to the combined brainpower of the team. Thus Zheng's (2012) study of the transactive memory systems of 98 Chinese start-ups finds that higher levels of transactive memory had positive effects on new venture performance, leading Zheng (2012, p. 580) to suggest that 'transactive memory systems enable team members to assimilate and transfer information in a more organized manner, reducing the cognitive resource demand for the entire team'. We add that it is not much of a leap to conclude from 
these results that ventures with better developed transactive memory systems can be said to 'think' better than those with less well-developed systems.

\section{Boundary objects as mediators of distributed cognition}

Highly visible, shared material objects such as hospital patient records, air traffic controller paper tapes and workflow charts are conspicuous tools for coordinating the action of multiple individuals in many complex environments (Klemmer et al. 2006). The production, manipulation and physical handover of such material objects support collaboration precisely because they are made visible to colleagues. The notion of boundary objects has a similar logic: they are artifacts that serve as triangulation points for individuals from different thought worlds and knowledge communities. Examples of boundary objects include tangible objects such as software programs, maps and scientific equipment (Nicolini et al. 2012) as well as more abstract objects such as strategy tools, concepts and stories (Bartel and Garud 2009; Spee and Jarzabkowski 2009). Nicolini et al. (2012) stress that an object's status as a boundary object is not an inherent property of the object itself, but is contingent on the unfolding of work going on around it: '[T]he role and function of particular objects can change during the course of collaboration. The same object can thus take center stage or shift into the background at different times' (p. 612).

Such observations have an air of familiarity to entrepreneurship researchers, because several material objects are very common and conspicuous in the entrepreneurial process, and serve to organize it in important ways. Among these are business ideas, prototypes, entrepreneurial opportunities, business models and business plans. Collectively, this set of objects composes an infrastructure that serves the entrepreneurial process. Traditionally, researchers conceptualized these objects mostly through an essentialist lens, i.e. as instruments in the venture creation process. For example, business ideation has been intensively researched in terms of its role in predicting new venture success (Åstebro and Elhedhli 2006; Goldenberg et al. 2001), the instrumental efficiency of business planning has received considerable attention over decades of research (meta analyzed by Brinckmann et al. 2010), the role of business model innovation in value creation has been investigated (Zott and Amit 2013), and the use of prototypes has also been explored, in particular in relation to new venture or new product success (Kakati 2003; Mullins and Sutherland 1998; Ries 2011). Business plans provide a vivid example of boundary objects, since they tend to bridge diverse actors - the entrepreneur, co-founders, employees, potential investors, suppliers and bankers. They exhibit the dominant characteristic of boundary objects highlighted in the literature - interpretive flexibility (Star 2010; Star and Griesemer 1989) - i.e. the flexibility for diverse individuals to incorporate the object into their system of activity, combined with robustness in the face of multiple interpretations. Business plans get used by design engineers as well as venture capitalists (Henderson 1991).

However, above all these objects, the articulation of opportunity has occupied a central position in the scholarly field over the past 10 years (Dimov 2011; Shane 2000; Shane and Eckhardt 2003; Venkataraman 1997). Boundaries are gaps, like differences in relative expertise and knowledge domains (Greer et al. 2005), reflecting the information and knowledge asymmetry of an entrepreneurial agent and potential stakeholders to act and interact on an innovative market opportunity. Therefore, the opportunity as a boundary object provides a bridge between individuals (for example, those who perceive an opportunity and those who do not) by triangulating on something in common, by facilitating a flow of information and knowledge (Carlile 2004) and by reducing time required for sense-making (Cornelissen and Clarke 2010; Wood and McKinley 2010). Garud and Giuliani (2013) and Bartel and Garud (2009) have been particularly eloquent on this point by arguing that narratives act as boundary objects and that meaningful entrepreneurial narratives involve the definition of an opportunity. In their words, '[M] eaning making involves the definition of an opportunity as entrepreneurs "plot" sets of social and material elements from the past, present and future into a comprehensible narrative' (Garud and Giuliani 2013, p. 159). Therefore, entrepreneurs do more than outline the opportunity for themselves when they describe opportunities; they typically wrap familiar stories around opportunities as a way of translating these opportunities for audiences that have different knowledge bases. In doing so, they try to make it easier for other agents to 'lean on the world' (Clark 1997), i.e. to use these objects as elements in their own distributed systems of cognition (Smith and Semin 2004, pp. 89-90).

In sum, insights from the transactive memory and boundary objects literatures fall very naturally into 
the overall perspective of situated cognition research, with its claim that cognition can be analyzed in terms of its system-level properties, i.e. in terms of how ventures think, remember and create. This has important implications for entrepreneurial cognition research, where the traditional focus has been on individual cognition, on the brain inside its 'skinbag' (Clark 1997). The analysis of distributed cognition therefore opens up several possibilities for freshly conceptualizing cognition in entrepreneurship.

\section{Discussion of future research directions}

\section{Inventorying situated cognition at work in entrepreneurship}

In this final section of the paper, we explore future entrepreneurship research that might exploit the foregoing overlapping theses of embedded, grounded and distributed cognition. We start with the need for inventorying examples of situated cognition that are more and less frequently occurring in the entrepreneurship domain, a task we see as vital at this stage of the research. Our first observation pertains to objects. In the course of their work, entrepreneurs use and create a rich variety of physical and conceptual objects, some of which have already seen extensive study (such as business plans and product ideas) and some which have not (such as physical office configuration and the organization of information on computers). Recent work by Clarke (2011) and Cornelissen et al. (2012) has previously pointed the way to documenting these phenomena, and much more could be done, including the reinterpretation of both primary and secondary sources that were originally created without the intention of documenting instances of situated cognition (for example: Chen et al. 2009; or Uzzi 1997). In general, we encourage research that leverages the natural setting of entrepreneurial activities in order to gather as much information as possible about the ways in which entrepreneurs leverage 'tools and other artifacts, aspects of the environment, other people and groups' (Smith and Semin 2004, p. 89).

Our second suggestion pertains to the entrepreneurial process. There is a long history in entrepreneurship research investigating steps in the process by which entrepreneurs advance new venture creation (Gartner 2004). Because that literature has made good progress in operationalization, methods and measures can readily be adopted and adapted to investigate how situated entrepreneurial cognition maps onto different steps in the entrepreneurial process. For example, Zheng (2012) cites that Google's two founders worked together at Stanford University for several years before starting the firm, implying that they learned to transact memory in the pre-firm period. Therefore, as one example of mapping the elements of situated cognition to venture stage, research might usefully examine whether transactive memory is generally more important in the very early days of a venture, or in more established small and mediumsized enterprises and inter-firm networks (Majchrzak et al. 2007).

Third, some innovation in research methods is encouraged, particularly the use of photography and video to evidence phenomenon of interest. A canonical example of this is Hutchins' various studies of navigation (Hutchins 1995a,b, 2005) that use a carefully crafted anthropological approach, with ample capture of the phenomenon of interest using modern media tools. Hutchins point is to capture evidence of the interplay of multiple distributed elements in cognition. Ultimately, Hutchins wants us to realize that there are times when it is useful to dispense almost entirely with studying cognition by focusing on what goes on inside an individual mind and, instead, focus on properties of the external system going on around the individual. One of his arguments is that an advantage of this approach to studying cognition is that one can use direct observation and photography to record phenomena of interest. Nicolini et al. (2012), Clarke and Cornelissen (2011) and Cornelissen et al. (2012) similarly use visual ethnographic approaches to good effect, but such methodological innovations remain quite rare in the literature.

Fourth, the examples of data-gathering above point to another and equally promising avenue of future research that emerges from the fact that the three theses of situated entrepreneurial cognition are not independent categories and do not necessarily represent a singular construct. For instance, embedding and grounding can be argued to also imply distributed cognition. In our exposition of these concepts, we have exerted care to give the three theses different foci in order to reduce these overlaps, but we acknowledge that others might disagree with our categorization (e.g. Hutchins, 1995b; or Smith and Semin 2004). Therefore, cleanly operationalizing the different conceptual elements within situated entrepreneurial cognition offers an excellent opportunity for contribution and advancement of theory around the phenomenon. 
Theory and empirical evidence linking situated cognition to DVs, and moderators thereof

Again in the spirit of building on prior work, over the years there has been extensive work on entrepreneurial outcomes (Mayer-Haug et al. 2013). For many researchers, the true value of entrepreneurial cognition research lies in linking cognitive phenomena to dependent variables meaningful in the entrepreneurial context (Mitchell et al. 2007). The traditional variables around venture performance, growth and failure rates are highly relevant here as ultimate measures of the impact of cognitive performance in entrepreneurship. However, there are also more proximate variables that seem highly appropriate as meaningful measures of the impact of elements of situated cognition, and that have relatively straightforward theoretical links to elements of situated cognition. Examples include measures of sensegiving impact (e.g. ease and speed of comprehension of embodied concepts), measures of the impact and effectiveness of boundary objects (e.g. business plans, prototypes, venture stories: Bartel and Garud 2009), measures of success in entraining stakeholders (e.g. to raise funding, obtain social support, other needed resources: Martens et al. 2007), and measurements of top team performance in ventures (e.g. impact of transactive memory: e.g. Zheng 2012).

Theoretically informed moderators of these relationships might include some that are entrepreneur focused (such as experience and/or expertise), some that vary with the venture type (such as the pace of venture development and novelty of the offering) and some that reflect environment type (such as the degree of uncertainty). These features of the entrepreneurial situation offer special advantages to future researchers as they enable testing of the circumstances in which elements of situated cognition matter more or less. For example, Cornelissen and Clarke (2010, p. 544) hypothesize that the use of embodied conceptualizations is a function of the degree to which an entrepreneur has had previous experiences in the same or similar industries, with novice entrepreneurs expected to rely more on embodied concepts, while entrepreneurs with relevant industry experience are expected to use industry analogies that are known to them. Serial and lifelong entrepreneurs experience large numbers of outcomes in the course of their entrepreneurial journeys and, from theoretical perspectives on expertise and heuristics, these events are likely to shape their cognition moving ahead (Mitchell et al. 2000), such as whether they take a more effectual or predictive approach to venturing (Sarasvathy 2001). It would be valuable to understand whether experienced and/or expert entrepreneurs also differ from novice entrepreneurs in how they exploit cognitive embeddedness, embodiment and distributed cognition and - if they do - how such differences relate to effectuation or predictive approaches (Sarasvathy and Venkataraman 2011).

With regard to the pace of venture development and novelty level, scholars have been aware ever since Eisenhardt's (1989) studies that high velocity decision-making involves using information more intensively, not less. It would be valuable to understand how the elements of situated cognition are involved in using information more intensively, since the principles of bounded cognition would imply that decision-makers will have to find ways of stretching their cognitive resources (Tribble 2005), potentially by leaning more intensively on their environment, each other and bodies. The same logic applies to highly technical, high novelty ventures where we know little about what types of cognitive supports entrepreneurs use routinely and more/less intensively. Does novelty drive more or less intensive use of transactive memory? Or is it prototyping that is more intensively used for scaffolding cognition in highly novel ventures?

Finally, the impact of uncertainty is a perennial issue for entrepreneurship scholars. How is cognition scaffolded in high uncertainty situations? Are there important differences between high and low uncertainty contexts? For example, to what extent is business planning a cognitive scaffold and how does it vary in low and high uncertainty environments (Gruber 2007)?

\section{How much influence do people have on their own situated cognition?}

Looking ahead to future research, another key issue is how much influence individuals exert on their own situated cognition. The ship pilot, in conjunction with the shipwright who constructed the pilothouse with its cognitive extension tools, appears to exert proactive control over the cognitive elements involved in navigating a ship. Yet, a parallel stream of research assigns cognitive abilities to far more innate variables that include genetics, hormones and hardwiring (Barkow et al. 1992; Nicolaou et al. 2008; White et al. 2007). Therefore, there is an important opportunity to untangle the role of 
individual agency in its own situated cognition by investigating when and how entrepreneurs build the scaffolding that supports their cognition, and the consequences of that. Importantly, from a situated cognition perspective, there is a case for supposing that using environmental supports (via embedding, distributing and embodying mechanisms) has longterm (and maybe short-term) consequences for our inner cognitive capacities; that it is unlikely that the 'inner machine' is left the same as before (Sterelny 2010). The scaffold-constructing activities of entrepreneurs may be culturally transmitted over decades or centuries, but perhaps also over shorter periods of time (consider, for example, the influence of the now ubiquitous Microsoft Powerpoint as a cognitive crutch). Thus, researchers ought to study the implications of situated cognition for the full range of ways in which entrepreneurs might be constructing and re-constructing cognitive capabilities over time.

\section{Philosophical differences}

Finally, we would be remiss not to remind readers that there are also a number of thorny philosophical differences that arise out of research on situated cognition. The philosophy literature around situated cognition has fiercely debated the meaning of so much cognitive learning on the world. For example, Hutchins (1995b) sees the mental realm as being unevenly distributed across the elements of a system that incorporates material objects, body and others. Analyzing in this way leads Hutchins to suggest that it makes more sense to see the cockpit of the aircraft (the system) rather than the pilot as remembering its speed. Clark and Chalmers (1998) famously used a thought experiment about Otto, an Alzheimer sufferer who uses a notebook as a substitute for his memory (information residing on one's iPhone being another example: Clark 2008). By focusing on the isomorphism and parity between notebook and memory, Clark and Chalmers argue that cognition need not be conceptualized as only what is inside the head, but can, instead, be analyzed as an extended system. Sutton (2010) argues that the more one studies the mind, the more one realizes that it is powerful precisely because it co-opts external resources that complement its internal capabilities. For new venture teams, different team members can be thought of as similarly providing specialized cognitive resources to one another. However, some researchers (e.g. Wilson 2002) strongly object to conceptualizing cognition as extended, and others (e.g. Sterelny 2010) point out that many human capacities, not just cognition, 'depend on the fact that humans engineer their environment to support their activities' (p. 466), and hence argue that situated cognition is a special case of the more general phenomenon that human capabilities are environmentally scaffolded. Therefore, we think that some entrepreneurial cognition researchers will balk at the idea of cognition being conceptualized as looping outside the head, and the various differing perspectives on the meaning of situated cognition in the specific domain of entrepreneurship will demand continued attention in the literature.

\section{Conclusion}

We conclude by emphasizing that we share the wish of other scholars to see entrepreneurship research fundamentally socialize the entrepreneur, in a broad sense of the term (Venkataraman et al. 2012). We believe that the literature reviewed in this paper offers an important point of departure for novel research on entrepreneurial cognition, because it puts the whole person into the analysis, richly connected with other agents, incorporating their entire corpus and interacting with a material world full of ordinary objects that have surprising cognitive lives. We therefore sense a tremendous opportunity to incorporate a truly situated conception of cognition into existing research on entrepreneurship where, despite some significant work that moves the field in this direction (Cornelissen and Clarke 2010; Mitchell et al. 2011; Randolph-Seng et al. in press), to date it remains an underexplored opportunity.

\section{References}

Agre, P.E. (1997). Computation and Human Experience. New York, NY: Cambridge University Press.

Anderson, M.L. (2003). Embodied cognition: a field guide. Artificial Intelligence, 149, pp. 91-130.

Åstebro, T. and Elhedhli, S. (2006). The effectiveness of simple decision heuristics: forecasting commercial success for early-stage ventures. Management Science, 52, pp. 395-409.

Austin, J.R. (2003). Transactive memory in organizational groups: the effects of content, consensus, specialization, and accuracy on group performance. Journal of Applied Psychology, 88, pp. 866-878.

Austin, R.D., Devin, L. and Sullivan, E.E. (2012). Accidental innovation: supporting valuable unpredictability in the creative process. Organization Science, 23, pp. 15051522. 
Baker, T. and Nelson, R.E. (2005). Creating something from nothing: resource construction through entrepreneurial bricolage. Administrative Science Quarterly, 50, pp. 329366.

Barkow, J.H., Cosmides, L.E. and Tooby, J.E. (1992). The Adapted Mind: Evolutionary Psychology and the Generation of Culture. Oxford: Oxford University Press.

Baron, R.A. (2007). Behavioral and cognitive factors in entrepreneurship: entrepreneurs as the active element in new venture creation. Strategic Entrepreneurship Journal, 1, pp. 167-182.

Baron, R.A. (2008). The role of affect in the entrepreneurial process. Academy of Management Review, 33, pp. 328340.

Baron, R.A. and Ensley, M.D. (2006). Opportunity recognition as the detection of meaningful patterns: evidence from comparisons of novice and experienced entrepreneurs. Management Science, 52, pp. 1331-1344.

Barsalou, L.W. (2010). Grounded cognition: past, present and future. Topics in Cognitive Science, 2, pp. 716-724.

Bartel, C.A. and Garud, R. (2009). The role of narratives in sustaining organizational innovation. Organization Science, 20, pp. 107-117.

Baucus, D., Baucus, M. and Mitchell, R. (in press). Lessons from the neural foundation of entrepreneurial cognition: the case of emotion and motivation. In Mitchell, J.R., Mitchell, R.K. and Randolph-Seng, B. (eds), The Handbook of Entrepreneurial Cognition. Northampton, MA: Edward Elgar, in press.

Baum, J.R. and Locke, E.A. (2004). The relationship of entrepreneurial traits, skill, and motivation to subsequent venture growth. Journal of Applied Psychology, 89, pp. 587-598.

Baumol, W.J. (2010). The Microtheory of Innovative Entrepreneurship. Princeton, NJ: Princeton University Press.

Bettiol, M., Di Maria, E., Finotto, V. and Micelli, S. (2013). The hidden side of innovation: why tinkerers matter. Proceedings from 35th Druid Celebration Conference.

Birkinshaw, J. (2000). Entrepreneurship in the Global Firm: Enterprise and Renewal. Thousand Oaks, CA: Sage.

Blau, P.M. (1970). A formal theory of differentiation in organizations. American Sociological Review, 35, pp. 201-218.

Brandon, D.P. and Hollingshead, A.B. (2004). Transactive memory systems in organizations: matching tasks, expertise, and people. Organization Science, 15, pp. 633-644.

Braudel, F. (1982). Civilization and Capitalism, 15th-18th Century: The Wheels of Commerce, Vol. 2. Oakland CA: University of California Press.

Breugst, N., Domurath, A., Patzelt, H. and Klaukien, A. (2012). Perceptions of entrepreneurial passion and employees' commitment to entrepreneurial ventures. Entrepreneurship Theory and Practice, 36, pp. 171-192.

Brinckmann, J., Grichnik, D. and Kapsa, D. (2010). Should entrepreneurs plan or just storm the castle? A metaanalysis on contextual factors impacting the business planning-performance relationship in small firms. Journal of Business Venturing, 25, pp. 24-40.

Brooks, R.A. (1991). Intelligence without representation. Artificial Intelligence Journal, 47, pp. 139-159.

Brush, C.G. (1992). Market place information scanning practices of new manufacturing ventures. Journal of Small Business Management, 30, pp. 41-53.

Burt, R.S. (2009). Structural Holes: The Social Structure of Competition. Cambridge, MA: Harvard University Press.

Busenitz, L.W. and Barney, J.B. (1997). Differences between entrepreneurs and managers in large organizations: biases and heuristics in strategic decision-making. Journal of Business Venturing, 12, pp. 9-30.

Cardon, M.S. (2008). Is passion contagious? The transference of entrepreneurial passion to employees. Human Resource Management Review, 18, pp. 77-86.

Cardon, M.S., Wincent, J., Singh, J. and Drnovšek, M. (2009). The nature and experience of entrepreneurial passion. Academy of Management Review, 34, pp. 511532.

Carlile, P.R. (2004). Transferring, translating, and transforming: an integrative framework for managing knowledge across boundaries. Organization Science, 15, pp. 555-568.

Caves, R.E. and Porter, M.E. (1977). From entry barriers to mobility barriers: conjectural decisions and contrived deterrence to new competition. Quarterly Journal of Economics, 91, pp. 241-262.

Cetina, K.K. (1997). Sociality with objects: social relations in postsocial knowledge societies. Theory, Culture \& Society, 14, pp. 1-30.

Chen, X.P., Yao, X. and Kotha, S. (2009). Entrepreneur passion and preparedness in business plan presentations: a persuasion analysis of venture capitalists' funding decisions. Academy of Management Journal, 52, pp. 199-214.

Clancey, W.J. (1997). Situated Cognition: On Human Knowledge and Computer Representations. Cambridge: Cambridge University Press.

Clark, A. (1997). Being There: Putting Brain, Body, and World Together Again. Cambridge, MA: MIT press.

Clark, A. (1999). Embodied, situated and distributed cognition. In Bechtel, W. and Graham, G. (eds), A Companion to Cognitive Science. Oxford: Basil Blackwell, pp. 506517.

Clark, A. (2008). Supersizing the Mind: Embodiment, Action, and Cognitive Extension: Embodiment, Action, and Cognitive Extension. Oxford: Oxford University Press.

Clark, A. (2010). Memento's revenge: the extended mind, extended. In Menary, R. (ed.), The Extended Mind. Cambridge, MA: MIT Press, pp. 43-66.

Clark, A. and Chalmers, D. (1998). The extended mind. Analysis, 58, pp. 7-19.

Clarke, J. (2011). Revitalizing entrepreneurship: how visual symbols are used in entrepreneurial performances. Journal of Management Studies, 48, pp. 1365-1391. 
Clarke, J.S. and Cornelissen, J.P. (2011). Language, communication and socially situated cognition in entrepreneurship. Academy of Management Review, 36, pp. 776-778.

Cooper, A.C. and Bruno, A.V. (1977). Success among hightechnology firms. Business Horizons, 20, pp. 16-22.

Cornelissen, J.P. (2013). Portrait of an entrepreneur: Vincent van Gogh, Steve Jobs, and the entrepreneurial imagination. Academy of Management Review, 38, pp. 700-709.

Cornelissen, J.P. and Clarke, J.S. (2010). Imagining and rationalizing opportunities: inductive reasoning, and the creation and justification of new ventures. Academy of Management Review, 35, pp. 539-557.

Cornelissen, J.P., Clarke, J. and Cienki, A. (2012). Sensegiving in entrepreneurial contexts: the use of metaphors in speech and gesture to gain and sustain support for novel ventures. International Small Business Journal, 30, pp. 213-241.

Damasio, A.R. (1994). Descartes' Error: Emotion, Reason and the Human Brain. New York, NY: Avon Books.

Davidsson, P. and Honig, B. (2003). The role of social and human capital among nascent entrepreneurs. Journal of Business Venturing, 18, pp. 301-331.

Davis, L.N., Davis, J.D. and Hoisl, K. (2013). Leisure time invention. Organization Science, 24, pp. 1439-1458.

De Carolis, D.M. and Saparito, P. (2006). Social capital, cognition, and entrepreneurial opportunities: a theoretical framework. Entrepreneurship Theory and Practice, 30, pp. 41-56.

Dimov, D. (2007). Beyond the single-person, single-insight attribution in understanding entrepreneurial opportunities. Entrepreneurship Theory and Practice, 31, pp. 713731.

Dimov, D. (2010). Nascent entrepreneurs and venture emergence: opportunity confidence, human capital, and early planning. Journal of Management Studies, 47, pp. 11231153.

Dimov, D. (2011). Grappling with the unbearable elusiveness of entrepreneurial opportunities. Entrepreneurship Theory and Practice, 35, pp. 57-81.

Doganova, L. and Eyquem-Renault, M.E. (2009). What do business models do?: Innovation devices in technology entrepreneurship. Research Policy, 38, pp. 1559-1570.

Drnovšek, M., Cardon, M.S. and Murnieks, C.Y. (2009). Collective passion in entrepreneurial teams. In Carsrud, A.L. and Brannback, M.E. (eds), Understanding the Entrepreneurial Mind. New York, NY: Springer, pp. 191215.

Drnovšek, M., Slavec, A. and Cardon, M.S. (in press). Cultural context, passion, and self-efficacy: do entrepreneurs operate on different 'planets'? In Mitchell, J.R., Mitchell, R.K. and Randolph-Seng, B. (eds), The Handbook of Entrepreneurial Cognition. Northampton MA: Edward Elgar, in press.

Eisenhardt, K.M. (1989). Making fast strategic decisions in high-velocity environments. Academy of Management Journal, 32, pp. 543-576.
Eisenhardt, K.M. and Schoonhoven, C.B. (1990). Organizational growth: linking founding team, strategy, environment, and growth among U.S. semiconductor ventures, 1978-1988. Administrative Science Quarterly, 35, pp. 504-529.

Fligstein, N. (2001). The Architecture of Markets: An Economic Sociology of Capitalist Societies. Princeton, NJ: Princeton University Press.

Frese, M. et al. (2007). Business owners' action planning and its relationship to business success in three African countries. Journal of Applied Psychology, 92, pp. 14811498.

Friedel, R.D. (2007). A Culture of Improvement: Technology and the Western Millennium. Cambridge, MA: MIT Press.

Gartner, W.B. (ed.) (2004). Handbook of Entrepreneurial Dynamics: The Process of Business Creation. Thousand Oaks, CA: Sage.

Garud, R. and Giuliani, A.P. (2013). A narrative perspective on entrepreneurial opportunities. Academy of Management Review, 38, pp. 157-160.

Garud, R. and Karnøe, P. (2003). Bricolage versus breakthrough: distributed and embedded agency in technology entrepreneurship. Research Policy, 32, pp. 277-300.

Geroski, P. (2003). The Evolution of New Markets. Oxford: Oxford University Press.

Goldenberg, J., Lehmann, D.R. and Mazursky, D. (2001). The idea itself and the circumstances of its emergence as predictors of new product success. Management Science, 47, pp. 69-84.

Goldin-Meadow, S. and Wagner, S. (2005). How our hands help us learn. Trends in Cognitive Sciences, 9, pp. 234241.

Greer, D.R., Black, L.J. and Adams, R.J. (2005). Identifying and mitigating risk across organizational boundaries in software-intensive space system programs. Proceedings of the 2005 Space Systems Engineering \& Risk Management Symposium.

Grégoire, D.A., Corbett, A.C. and McMullen, J.S. (2011). The cognitive perspective in entrepreneurship: an agenda for future research. Journal of Management Studies, 48, pp. 1443-1477.

Gruber, M. (2007). Uncovering the value of planning in new venture creation: a process and contingency perspective. Journal of Business Venturing, 22, pp. 782807.

Hare, A.P., Borgotta, E.F. and Bales, R.F. (1965). Small Groups: Studies in Social Interaction. New York, NY: Knopf.

Harnad, S. (1990). The symbol grounding problem. Physica D: Nonlinear Phenomena, 42, pp. 335-346.

Hayek, F.A. (1945). The use of knowledge in society. American Economic Review, 34, pp. 519-530.

Hayek, F.A. (1978). New Studies in Philosophy, Politics, Economics, and the History of Ideas. London: Routledge. Haynie, J.M., Shepherd, D.A., Mosakowski, P. and Earley, P.C. (2010). A situated metacognitive model of the 
entrepreneurial mindset. Journal of Business Venturing, 25, pp. 217-229.

Hayward, M., Shepherd, D.A. and Griffin, D. (2006). A hubris theory of entrepreneurship. Management Science, 52, pp. 160-172.

Heckhausen, J. and Heckhausen, H. (2008). Motivation and Action. New York, NY: Cambridge University Press.

Henderson, K. (1991). Flexible sketches and inflexible data bases: visual communication, conscription devices, and boundary objects in design engineering. Science, Technology and Human Values, 16, pp. 448-473.

Hollingshead, A.B. (1998). Communication, learning, and retrieval in transactive memory systems. Journal of Experimental Social Psychology, 34, pp. 423-442.

Hostetter, A. and Alibali, M. (2008). Visible embodiment: Gestures as simulated action. Psychonomic Bulletin \& Review, 15, pp. 495-514.

Hutchins, E. (1995a). Cognition in the Wild. Cambridge, MA: MIT Press.

Hutchins, E. (1995b). How a cockpit remembers its speed. Cognitive Science, 19, pp. 265-288.

Hutchins, E. (2005). Material anchors for conceptual blends. Journal of Pragmatics, 37, pp. 1555-1577.

Hutchins, E. (2006). The distributed cognition perspective on human interaction. In Enfield, N.J. and Levinson, S.C. (eds), Roots of Human Sociality: Culture, Cognition and Interaction. Oxford: Berg, pp. 375-398.

Iverson, J.M. and Goldin-Meadow, S. (1998). Why people gesture when they speak. Nature, 396, p. 228.

Jacob, F. (1977). Evolution and tinkering. Science, 196, pp. 1161-1166.

James, W. (1904). A world of pure experience. Journal of Philosophy, Psychology, and Scientific Methods, 1, pp. 533-543.

Joas, H. (1996). The Creativity of Action. Chicago, IL: University of Chicago Press.

Kakati, M. (2003). Success criteria in high-tech new ventures. Technovation, 23, pp. 447-457.

Kim, W.C. and Mauborgne, R. (2005). Blue Ocean Strategy: How to Create Uncontested Market Space and Make the Competition Irrelevant. Boston, MA: Harvard University Press.

Kirzner, I.M. (1979). Perception, Opportunity and Profit: Studies in the Theory of Entrepreneurship. Chicago, IL: University of Chicago Press.

Kirzner, I.M. (1985). Discovery and the Capitalist Process. Chicago, IL: University of Chicago Press.

Kirzner, I.M. (1997). Entrepreneurial discovery and the competitive market process: an Austrian approach. Journal of Economic Literature, 35, pp. 60-85.

Klein, P. (2008). Opportunity discovery, entrepreneurial action, and economic organization. Strategic Entrepreneurship Journal, 2, pp. 175-190.

Klemmer, S.R., Hartmann, B. and Takayama, L. (2006). How bodies matter: five themes for interaction design.
Proceedings of the 6th Conference on Designing Interactive systems, pp. 140-149.

Klotz, A.C., Hmieleski, K.M., Bradley, B.M. and Busenitz, L.W. (2014). New venture teams: a review of the literature and roadmap for future research. Journal of Management, 40, pp. 226-255.

Koehn, N.F. (2000). Brand New: How Entrepreneurs Earned Consumers' Trust from Wedgwood to Dell. Cambridge, MA: Harvard Business Press.

Krueger Jr, N.F., Reilly, M.D. and Carsrud, A.L. (2000). Competing models of entrepreneurial intentions. Journal of Business Venturing, 15, pp. 411-432.

Lakoff, G. and Johnson, M. (1980). The metaphorical structure of the human conceptual system. Cognitive Science, 4, pp. 195-208.

Lakoff, G. and Johnson, M. (1999). Philosophy in the Flesh: The Embodied Mind and Its Challenge to Western Thought. New York, NY: Basic Books.

Latour, B. (1987). Science in Action. Cambridge, MA: Cambridge University Press.

Latour, B. (1996). On interobjectivity. Mind, Culture, Activity, 3, pp. 228-245.

Lindblom, C. (1959). The science of 'muddling through'. Public Administration Review, 19, pp. 79-88.

Locke, E.A. and Baum, J.R. (2007). Entrepreneurial motivation. In Baum, J.R., Frese, M. and Baron, R.A. (eds), The Psychology of Entrepreneurship. The Organizational Frontiers. Mahwah, NJ: Lawrence Erlbaum Associates, pp. 93-112.

Majchrzak, A., Jarvenpaa, S.L. and Hollingshead, A.B. (2007). Coordinating expertise among emergent groups responding to disasters. Organization Science, 18, pp. 147-161.

Martens, M.L., Jennings, J.E. and Deveraux Jennings, P.D. (2007). Do the stories they tell get them the money they need? The role of entrepreneurial narratives in resource acquisition. Academy of Management Journal, 50, pp. 1107-1132.

Mayer-Haug, K., Read, S., Brinckmann, J., Dew, N. and Grichnik, D. (2013). Entrepreneurial talent and venture performance: a meta-analytic investigation of SMEs. Research Policy, 42, pp. 1251-1273.

McClelland, D.C. (1962). Business drive and national achievement. Harvard Business Review, 40, pp. 99112.

McMullen, J.S. and Shepherd, D.A. (2006). Entrepreneurial action and the role of uncertainty in the theory of the entrepreneur. Academy of Management Review, 31, pp. 132-152.

McNeill, D. (2005). Gesture and Thought. Chicago, IL: University of Chicago Press.

Mitchell, J.R., Mitchell, R.K. and Randolph-Seng, B. (in press). The Handbook of Entrepreneurial Cognition. Northampton MA: Edward Elgar, in press.

Mitchell, R.K., Randolph-Seng, B. and Mitchell, J.R. (2011). Socially situated cognition: imagining new 
opportunities for entrepreneurship research. Academy of Management Review, 36, pp. 774-776.

Mitchell, R.K., Smith, B., Seawright, K.W. and Morse, E.A. (2000). Cross-cultural cognitions and the venture creation decision. Academy of Management Journal, 43, pp. 974993.

Mitchell, R.K. et al. (2007). The central question in entrepreneurial cognition research 2007. Entrepreneurship Theory and Practice, 31, pp. 1-27.

Mokyr, J. (1990). The Lever of Riches: Technological Creativity and Economic Progress. New York, NY: Oxford University Press.

Mullins, J.W. and Sutherland, D.J. (1998). New product development in rapidly changing markets: an exploratory study. Journal of Product Innovation Management, 15, pp. 224-236.

Nicolaou, N., Shane, S., Cherkas, L. and Spector, T.D. (2008). The influence of sensation seeking in the heritability of entrepreneurship. Strategic Entrepreneurship Journal, 2, pp. 7-21.

Nicolini, D., Mengis, J. and Swan, J. (2012). Understanding the role of objects in cross-disciplinary collaboration. Organization Science, 23, pp. 612-629.

Nooteboom, B. (1994). Innovation and diffusion in small firms: theory and evidence. Small Business Economics, 6 , pp. 327-347.

O'Regan, J.K. (1992). Solving the 'real' mysteries of visual perception: the world as an outside memory. Canadian Journal of Psychology, 46, p. 461-488.

Orlikowski, W.J. (2007). Sociomaterial practices: exploring technology at work. Organization Studies, 28, pp. 14351448.

Penrose, E.T. (1959). The Theory of the Growth of the Firm. Oxford: Oxford University Press.

Piaget, J. (1952). The Origins of Intelligence in Children. New York, NY: International University Press.

Porter, M.E. (1980). Competitive Strategy: Techniques for Analysing Industries and Competitors. New York, NY: Free Press.

Prinz, W. (1987). Ideomotor action. In Heuer, H. and Sanders, A.F. (eds), Perspectives on Perception and Action. Hillsdale, NJ: Erlbaum, pp. 47-76.

Prinz, W. (2002). Experimental approaches to imitation. In Meltzoff, A.N. and Prinz, W. (eds), The Imitative Mind: Development, Evolution, and Brain Bases. New York, NY: Cambridge University Press, pp. 143-162.

Randolph-Seng, B., Mitchell, J.R. and Mitchell, R.K. (in press). Introduction: historical context, present trends, and future directions in entrepreneurial cognition research. In Mitchell, J.R., Mitchell, R.K. and Randolph-Seng, B. (eds), The Handbook of Entrepreneurial Cognition. Northampton MA: Edward Elgar, in press.

Rheinberger, H.J. (1997). Toward A History of Epistemic Things: Synthesizing Proteins in the Test Tube. Palo Alto, CA: Stanford University Press.
Ries, E. (2011). The Lean Startup: How Constant Innovation Creates Radically Successful Businesses. London: Portfolio Penguin.

Robbins, P. and Aydede, M. (2009a). The Cambridge Handbook of Situated Cognition. New York, NY: Cambridge University Press.

Robbins, P. and Aydede, M. (2009b). A short primer on situated cognition. In Aydede, M. and Robbins, P. (eds), 2009. The Cambridge Handbook of Situated Cognition. New York, NY: Cambridge University Press, pp. 36.

Rosenberg, N. (1976). Perspective on Technology. New York, NY: Cambridge U. Press.

Sapienza, H.J., Autio, E., George, G. and Zahra, S.A. (2006). A capabilities perspective on the effects of early internationalization on firm survival and growth. Academy of Management Review, 31, pp. 914-933.

Sarasvathy, S.D. (2001). Causation and effectuation: toward a theoretical shift from economic inevitability to entrepreneurial contingency. Academy of Management Review, 26, pp. 243-263.

Sarasvathy, S.D. and Venkataraman, S. (2011). Entrepreneurship as method: open questions for an entrepreneurial future. Entrepreneurship Theory and Practice, 35, pp. 113-135.

Schultz, H. and Jones Yang, D. (1997). Pour Your Heart into It: How Starbucks Built A Company One Cup at A Time. New York, NY: Hyperion.

Schumpeter, J.A. (1976). Capitalism, Socialism and Democracy. London: Routledge.

Semin, G.R. and Smith, E.R. (eds) (2008). Embodied Grounding: Social, Cognitive, Affective, and Neuroscientific Approaches. New York, NY: Cambridge University Press.

Shane, S. (2000). Prior knowledge and the discovery of entrepreneurial opportunities. Organization Science, 11, pp. 448-469.

Shane, S. and Eckhardt, J. (2003). The individualopportunity nexus. In Acs, Z.J. and Audretsch, D.B. (eds), Handbook of Entrepreneurship Research. Berlin: Springer, pp. 161-191.

Shane, S. and Venkataraman, S. (2000). The promise of entrepreneurship as a field of research. Academy of Management Review, 25, pp. 217-226.

Shepherd, D.A. and Sutcliffe, K.M. (2011). Inductive topdown theorizing: a source of new theories of organization. Academy of Management Review, 36, pp. 361-380.

Smilor, R.W. (1997). Entrepreneurship: reflections on a subversive activity. Journal of Business Venturing, 12, pp. 341-346.

Smith, E.R. and Semin, G.R. (2004). Socially situated cognition: cognition in its social context. Advances in Experimental Social Psychology, 36, pp. 53-117.

Spee, A.P. and Jarzabkowski, P. (2009). Strategy tools as boundary objects. Strategic Organization, 7, pp. 223232. 
Star, S.L. (2010). This is not a boundary object: reflections on the origin of a concept. Science, Technology \& Human Values, 35, pp. 601-617.

Star, S.L. and Griesemer, J.R. (1989). Institutional ecology, translations' and boundary objects: amateurs and professionals in Berkeley's Museum of Vertebrate Zoology, 1907-39. Social Studies of Science, 19, pp. 387420.

Sterelny, K. (2010). Minds: extended or scaffolded? Phenomenology and the Cognitive Sciences, 9, pp. 465-481.

Sutton, J. (2010). Exograms and interdisciplinarity: history, the extended mind, and the civilizing process. In Menary, R. (ed.), The Extended Mind. Cambridge, MA: MIT Press, pp. 189-225.

Sutton, R.I. and Hargadon, A. (1996). Brainstorming groups in context: effectiveness in a product design firm. Administrative Science Quarterly, 41, pp. 685-718.

Swan, J., Bresnen, M., Newell, S. and Robertson, M. (2007). The object of knowledge: the role of objects in biomedical innovation. Human Relations, 60, pp. 1809-1837.

Thelen, E., Schöner, G., Scheier, C. and Smith, L.B. (2001). The dynamics of embodiment: a field theory of infant perseverative reaching. Behavioral and Brain Sciences, 24, pp. 1-34.

Thomke, S.H. (2003). Experimentation Matters: Unlocking the Potential of New Technologies for Innovation. Boston, MA: Harvard Business School Press.

Tribble, E. (2005). Distribution cognition in the globe. Shakespeare Quarterly, 56, pp. 134-155.

Tyre, M.J. and Von Hippel, E. (1997). The situated nature of adaptive learning in organizations. Organization Science, 8, pp. 71-83.

Uzzi, B. (1997). Social structure and competition in interfirm networks: the paradox of embeddedness. Administrative Science Quarterly, 42, pp. 35-67.

Venkataraman, S. (1997). The distinctive domain of entrepreneurship research: an editor's perspective. In Katz, J. and Brockhaus, R. (eds), Advances in Entrepreneurship, Firm Emergence, and Growth, Vol. 3, Greenwich, CT: JAI Press, pp. 119-138.

Venkataraman, S., Dew, N. and Sarasvathy, S. (2008). Made as well as found. Unpublished manuscript, Darden
Graduate School of Business Administration, Charlottesville, VA.

Venkataraman, S., Sarasvathy, S.D., Dew, N. and Forster, W.R. (2012). Reflections on the 2010 AMR decade award: whither the promise? Moving forward with entrepreneurship as a science of the artificial. Academy of Management Review, 37, pp. 21-33.

Von Hippel, E. (1994). 'Sticky information' and the locus of problem solving: implications for innovation. Management Science, 40, pp. 429-439.

Von Hippel, E. and Tyre, M.J. (1995). How learning by doing is done: problem identification in novel process equipment. Research Policy, 24, pp. 1-12.

Vygotsky, L.S. (1986). Thought and Language. Cambridge, MA: MIT press.

Wegner, D.M. (1987). Transactive memory: a contemporary analysis of the group mind. In Mullan, B. and Goethals, G.R. (eds), Theories of Group Behavior. New York, NY: Springer, pp. 185-208.

West, G.P. (2007). Collective cognition: when entrepreneurial teams, not individuals, make decisions. Entrepreneurship Theory and Practice, 31, pp. 77-102.

White, R.E., Thornhill, S. and Hampson, E. (2007). A biosocial model of entrepreneurship: the combined effects of nurture and nature. Journal of Organizational Behavior, 28, pp. 451-466.

Wilson, M. (2002). Six views of embodied cognition. Psychonomic Bulletin \& Review, 9, pp. 625-636.

Wood, M.S. and McKinley, W. (2010). The production of entrepreneurial opportunity: a constructivist perspective. Strategic Entrepreneurship Journal, 4, pp. 66-84.

Zahra, S.A., Ireland, R.D. and Hitt, M.A. (2000). International expansion by new venture firms: international diversity, mode of market entry, technological learning, and performance. Academy of Management Journal, 43, pp. 925-950.

Zheng, Y. (2012). Unlocking founding team prior shared experience: a transactive memory system perspective. Journal of Business Venturing, 27, pp. 577-591.

Zott, C. and Amit, R. (2013). The business model: a theoretically anchored robust construct for strategic analysis. Strategic Organization, 11, pp. 403-411. 